\title{
How Will Moy, Chantale, Susan and Lola Make It Through Art School?
}

\section{Mariam Cooley}

I have either taught or studied with the women named in my title and for me, they personify the reasons for my study. While they will not be explicitly included in my study, keeping their names before me as I plan my research serves to remind me of the diversities among women, the complexity of their lives and the power of the art that they produce. Their learning experiences and those of other women students in Canadian Art Schools are the focus of my research project.

All these students are women who are well aware that they operate in a society that works to construct and impose a particular notion of what "being a woman" is supposed to mean. However, their names, and many others that I might have included, speak to me as well of the diversity of life experiences that women bring with them when they enter our classrooms and studios:

- A young Francophone Canadian pursuing her education with great enthusiasm but in a language that is not her mother tongue.

- A woman of Chinese ancestry, born in Canada, who has always spoken English, and who as an adult, was moved to re-assume the Chinese name that designates her position in the family.

-- A divorced woman in her late forties, with (as she says) "no visible means of support", who moved across Canada to Montreal in quest of change and challenge.

-- A young lesbian who has chosen the wonderfully ironic name "lola" as a deliberate gesture that forces all of us to confront the sexist, classist, moralistic stereotype which that name evokes in North American society.

I do not mean to suggest that these women are simply representatives of some group into which I (or whoever) assign them. Such designations cannot describe the complicated personal, social, cultural and political relationships in their lives. Nor do I mean to imply that such designations are, or should be, the preoccupation of their artistic production. I have come to know these particular students well enough to know the anxiety, pain and struggle of their lives. I am moved by the energy, the sensitivity, the poetry, the audacity and the humour of their work. I am impressed by their initiative and by their persistence. 
However, from the informal conversations that I have had with my students in the past year, it is clear that they feel that what happens to them in their studio classes and in the general Art School milieu aggravates their anxiety and fosters a sense of alienation; a feeling that they are not taken seriously; that their ideas are not valid contributions and that their work is of little consequence. As one woman told me, "He (the instructor) just wouldn't talk about my paintings! He would talk about his house, his car, and his family. He would ask me about my boyfriend. But it was as if my painting wasn't even there."

On the other hand, instructors often feel that work done by women is not well developed, that their ideas are not coherent and that, if in fact women do speak up in crits, their contributions may be inept and superficial. As artist-teachers we have to admit that the learning that we expect just isn't happening for some of the women in our classes. Androcentric theories were content to assume that innate characteristics of the female temperament explained such lack of success. The assumption persists that it is women's inability to meet the demands of the institution that is problematic, not the institution or its practices.

Feminist practice has launched a major challenge to the androcentric view that masculine experience represents all experience and any thing that does not fit that representation is an abnormality. In the field of cultural production feminist artists (too numerous to mention here), critics and art educators, (Lucy Lippard, Parker \& Pollock, Georgia Collins, Renee Sendall to mention only a few of the instigators of the most recent debates) have contributed to that effort. There is concern for the positive recognition of sexual difference, for the articulation of feminist perspectives on issues of subjectivity, agency, sexuality and feminist political practice and for the means of exploiting feminist knowledge in pedagogical practice.

The gap between these two positions requires clarification if the educational experiences of the many women students in our art schools are to provide a positive grounding for ongoing participation in their chosen areas of artistic practice. As well, issues of racial/ethnic/cultural diversity are making long overdue demands on artistic practice and pedagogical scholarship. These issues cannot be divorced from the concerns that women have as artists, students and teachers. They are inextricably entwined.

Feminism is a term that I use carefully these days. In academic and artistic circles it is a concept that encompasses a tremendous range of social, political, cultural and intellectual points of view, many of which are at variance with one another. One is obliged to consider one's position and one's words very carefully. In the popular imagination feminism retains monolithic, radical, even heretical connotations. Tragic repercussions here in Montreal have given us ample reason for caution. When I use the term here, I mean simply the conscious taking of women's perspectives on any given issue as a valid and necessary approach to a question.

Working Papers in Art Education 1992 
The concept of experience in the context of feminism as I am using the term, is particular and important to the issues of female subjectivity and agency. Teresa de Lauretis details a particular connotation of the term experience as, ". . a process by which, for all human beings, subjectivity is constructed"; a subjectivity produced through a process of,

... one's personal, subjective, engagement in the practices, discourses, and institutions that lend significance (value, meaning. and affect) to the events of the world. (de Lauretis 1984: 159)

Experience, understood in this way has important implications for how one may understand the impact of social, cultural and familial influences ("the events of the world") on women's art making and learning. As we consciously take a woman's perspective in an effort to understand women's experience in all its variations, artists, critics and art educators are producing a body of knowledge that brings new insights into the breadth of human artistic expression.

I am undertaking a descriptive, qualitative study in which I will accumulate a body of data that goes beyond the informal, anecdotal nature of most writing on the subject. I want to know how women themselves understand their lives as art students. I want to know what meanings they develop or assign to the events of their school day. I want to see their art work and I want to know how they think about their art making /art learning process. I want to hear how they describe and refiect upon the representation of their ideas in their work. I will be conducting loosely structured, video taped interviews with thirty undergraduate students, in their homes or studios where their work is available for clear and specific reference. From this grounded theory approach I hope to gain insights into the ways that women describe and understand their art learning /art making processes.

Such insights are possible only if the research process itselt is consistent with the circumstance, as Brown \& Gilligan came to realize through their study of girls' psychological development. In order to enter a relationship with the girls they were interviewing and to evoke sincere responses that permitted understanding to evolve, it was necessary that,

.... we ask not only who is speaking but who is listening, and this relational understanding of the research process shifts the nature of psychological work from a profession of truth to a practice of relationship in which truths can emerge or become clear. (Brown \& Gilligan 1992: 22-3)

The concept of a dialogic relationship between the artist /viewer and the artistic text, between teacher and student, and in this case, between researcher /interviewer and respondent is very much like concepts of aesthetic response proposed by Prof. Stanley Horner. Horner talks about a process of engagement with the work of art (student /respondent) into which

Working Papers in Art Education 1992 
one journeys with one's whole self, "into a dream time-space, engaging the 'active imagination' (Jung), [ . . . ] into a world of analogical flow, of associations, puns and put-ons." open to the meaning(s) that, "emerges at the intersection where expectation schema of a viewer's desire meet with those of the author's desire." (Horner 1989: 8) Horner's proposal for the process of aesthetic response and criticism in artistic practice maintains the concept of dialogue that is similar to Brown \& Gilligan's concern in psychology; that in

.... a relational practice, we attend to the relational dimensions of our listening, speaking, taking in, interpreting, and writing about the words and silences, the stories and narratives of other people. (Brown \& Gilligan 1992: 22)

Thus, the interpretation and presentation of this study can become a creative practice through which I may bring the students' voices into a continuing dialogue with existing theoretical and pedagogical discourses.

Mikhail Bakhtin proposed a concept of dialogue as founded on sympathetic understanding, a concept which he saw as

... not a mirroring, but a fundamentally and essentially new valuation ... [ which ] ... recreates the whole inner person in aesthetically loving categories for a new existence in a new dimension of the world. (Bakhtin in Holquist 1990: 103)

Such a "new existence in a new dimension" suggests that I can hope to propose new questions for curriculum, for teaching practice and perhaps for institutional organization that can optimize the art learning efforts that women make. My expectation is that I can propose approaches to teaching which will not only reflect the implications of new knowledge about women's artistic engagement and representation but which will also enable teachers. along with our students to actively contribute to the creation of new cultural meaning.

\section{References}

Bakhtin, Mikhail. (ca. 1920-23) Author and hero in aesthetic activity. in M. Holquist and V. Liapunov (Eds.). Art and answerability: Early essays by M.M. Bakhtin. Austin: University of Texas Press. 1990.

Brown, Lyn Mikel \& Carol Gilligan. 1992. Meeting at the crossroads: Women's psychology and women's development. Cambridge, Massachusetts and London: Harvard University Press.

Collins, Georgia, 1978. Reflections on the head of the Medusa. Studies in Art Education 19:2, 10-18. 
. 1979. Women and art: The problem of status. Studies in Art Education 21:1, 57-64.

Collins, Georgia \& Renee Sandell. 1984. Women, art and education. Reston, Virginia: National Art Education Association.

de Lauretis, Teresa. 1984. Alice doesn't: Feminism, semiotics, cinema. Bloomington: Indiana University Press.

Horner, Stanley. 1989. Responding to art: 2C \& not 2B: That is not a question. Unpublished paper.

Lippard, Lucy. 1976. From the center: Feminist essays on women's art. New York: E.P. Dutton \& Co. Inc.

Parker, Rozika \& Griselda Pollock. 1981. Old mistresses: Women, art and ideology. London: Routledge and Kegan Paul.

Sandell, Renee, 1979. Feminist art education: An analysis of the women's art movement as an educational force. Studies in Art Education 20:2, 18-28. 